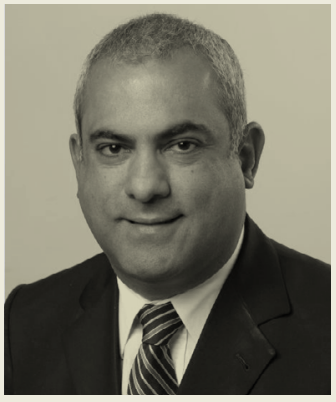

\title{
TRABALHO EM TEMPOS DE PANDEMIA: PERSPECTIVAS PARA 2021
}

Falar de perspectivas para o trabalho em 2021 comporta riscos muito grandes, pois, no momento, a sensação predominante é a de atordoamento, com planos e projetos em suspensão e foco concentrado na sobrevivência. A sensação que impera é a de estarmos atravessando uma tormenta severa, em que os ventos batem forte e podem produzir consequências que não conseguimos vislumbrar com o mínimo de clareza. Os riscos dessa análise, no entanto, têm potencial de ser recompensados se gerarem ações que levem ao fortalecimento da capacidade de enfrentamento dos desafios, que certamente serão enormes.

No campo do trabalho do administrador, forças de longo prazo foram surgindo do acúmulo e da interação de transformações sociais, econômicas, culturais, políticas, tecnológicas e organizacionais de diferentes intensidades e, muitas vezes, direcionadas em sentidos distintos. Entre elas, destaco três que me parecem ter impacto significativo no planejamento e na construção de trajetórias individuais:

OS DESAFIOS NESSES ÚLTIMOS MESES FIZERAM COM QUE O POR QUE E $O$ PARA QUE DAS ATIVIDADES A QUE NOS DEDICAMOS SE TORNASSEM AINDA MAIS ACENTUADOS. um diferencial competitivo importante, ainda que aplicada de maneira mais difusa. As movimentações internacionais continuarão a ocorrer e a exercer um amplo fascínio para determinados perfis de profissionais, mas exigirão um planejamento mais minucioso para lidar com pontos como: exigências de ingresso no país, permissões de trabalho e credenciais educacionais solicitadas ou valorizadas no mercado.

A tendência de se trabalhar em qualquer lugar e a qualquer hora já vinha se delineando com força há alguns anos. Ela foi acelerada pelas circunstâncias, que promoveram uma transformação abrupta do padrão de interação para geração de resultados. A potencialização desse cenário levou a uma valorização ainda maior de competências como habilidades computacionais, capacidade de trabalho em times virtuais, utilização de recursos digitais para aprimorar análises e comunicação, e capacidade de automotivação e disciplina no trabalho autônomo. Os desafios da realidade permitiram o desenvolvimento acelerado dessas competências por muitas pessoas. A continuidade dessa evolução das capacidades individuais e coletivas para enfrentar as dificuldades do trabalho remoto será uma marca deste ano e possivelmente dos próximos.

Finalmente, há a questão do propósito do trabalho. Os desafios nesses últimos meses fizeram com que o por que e o para que das atividades a que nos dedicamos se tornassem ainda mais acentuados. Essas perguntas conduzem a uma reflexão que orienta dois olhares: um para dentro, em busca do autoconhecimento ou da autoconstrução; outro para fora, em busca das oportunidades cambiantes de um mundo em transformação. O propósito é a tentativa de unificar esses dois olhares em uma perspectiva de vida que nos faça ter a sensação de que está valendo a pena.

Que a boa sorte acompanhe a todos, que valha a pena o esforço. 